\title{
Single subject research: use of interactive video in children with developmental disabilities with dyscalculia to introduce natural numbers
}

\author{
Sri Adi Widodo* \\ Department of Mathematics Education, Universitas Sarjanawiyata Tamansiswa, Yogyakarta, \\ Indonesia; ORCID: 0000-0001-8906-5190
}

Ayu Prihatiningsih

Department of Mathematics Education, Universitas Sarjanawiyata Tamansiswa, Yogyakarta, Indonesia; ORCID: 0000-0001-8906-5190

\section{Irham Taufiq}

Department of Mathematics Education, Universitas Sarjanawiyata Tamansiswa, Yogyakarta, Indonesia; ORCID: 0000-0001-7252-1049

\begin{tabular}{|c|c|}
\hline Article history & Dyscalculia is one of the barriers to learning for students with some \\
\hline $\begin{array}{l}\text { Received: } \\
10.06 .2020\end{array}$ & $\begin{array}{l}\text { special mental retardation needs. Students with intellectual disabilities } \\
\text { may also have dyscalculia. In that sense, in learning mathematics, it is }\end{array}$ \\
\hline $\begin{array}{l}\text { Received in revised form: } \\
18.11 .2020\end{array}$ & $\begin{array}{l}\text { necessary to use various learning media. Related to this condition, the } \\
\text { present study aims to determine the effect of the use of instructional } \\
\text { video media to introduce natural numbers to students who experience }\end{array}$ \\
\hline $\begin{array}{l}\text { Accepted: } \\
03.12 .2020\end{array}$ & $\begin{array}{l}\text { mental retardation with dyscalculia. This type of research is an } \\
\text { experimental research design with a single subject. This single-subject }\end{array}$ \\
\hline Key words: & research uses the A - B method. The research subjects were chosen based \\
\hline $\begin{array}{l}\text { interactive media, } \\
\text { mental retardation, } \\
\text { dyscalculia, } \\
\text { single subject research }\end{array}$ & $\begin{array}{l}\text { on a purposive sampling technique because the researchers had to find } \\
\text { subjects with mental retardation as well as dyscalculia characteristics } \\
\text { with these characteristics one elementary special school in Yogyakarta } \\
\text { was found. Data collection techniques involved using the method of } \\
\text { observation, interviews to determine the characteristics of the subject, } \\
\text { tests to determine the ability of subjects to recognize natural numbers. } \\
\text { The results of this study indicate that interactive media positively } \\
\text { influences the ability to recognize natural numbers in mentally retarded } \\
\text { children with dyscalculia. This can be seen from the average score } \\
\text { obtained by the subjects before being given an intervention that is } 30 \text { and } \\
\text { increased to } 54 \text { after being given an intervention. }\end{array}$ \\
\hline
\end{tabular}

\section{Introduction}

Mathematics has an important role in life, in addition to functioning as a tool for problem-solving, logical thinking, and reasoning, it also functions as a tool for communication between individuals (National of Council Teacher of Mathematics, 2000b; Stylianou et al., 2015; Widodo et al., 2019, 2020). However, learning mathematics becomes a very difficult

\footnotetext{
*Correspondency: : sriadi@ustjogja.ac.id;
} 
activity for mentally retarded children (Chodura et al., 2015; Dowker \& Sigley, 2010; Nuari et al., 2019; Scherer et al., 2017). This is because mentally retarded children experience inhibition of intelligence function, disability in social behavior or adaptation, and barriers to social behavior or adaptation that occur during the ages of development i.e. up to the age of 18 years (Baştürk, 2016; Dekker et al., 2016; El-Keshky \& Emam, 2015; Emam \& Kazem, 2015; Harvey \& Miller, 2017; Martin et al., 2017). Children with intellectual disabilities are generally children with special needs because they have an intellectual quotient below the average or intellectual quotient below 84 (Hegde \& Bhaskar, 2015; Kumar et al., 2009; Suchyadi et al., 2018; Teixeira et al., 2015; Van Schooneveld et al., 2016). So it is very natural that students with this category have difficulty learning mathematics. But if this lack of reasonableness is allowed to continue, students with special needs become unable to think logically, and mathematical communication weakens. The effect of students with this category is very dependent on the presence of others.

Also, students with dyscalculia experience learning difficulties (Kucian \& von Aster, 2015; Price \& Ansari, 2013; Shalev \& Gross-Tsur, 2001). Not only in mathematics, but also in learning languages, those students with dyscalculia characteristics have difficulty (Bugden \& Ansari, 2016; Skagerlund \& Träff, 2016; Torres-Carrión et al., 2018). In fact, dyscalculia is one of the barriers to learning in retarded children (Backenson et al., 2015; Bakare et al., 2010; Bran \& Bouleanu, 2017; Sridevi et al., 2015). Children with intellectual disabilities who experience dyscalculia have difficulty in mathematics, so one can imagine how difficult it is to learn mathematics for students with intellectual disabilities. The current study was conducted in class X Senior High School (special school) Bhakti Kencana 1 Berbah, Yogyakarta, Indonesia, with students who are still having difficulty in solving multiplication and division of natural numbers, they have not been able to link multiplication or division arithmetic operations with other arithmetic operations, these students are not careful in counting or are not focused when working on problems (Nuari \& Prahmana, 2018).

Even though studying mathematics for mentally retarded children and dyscalculia is challenging (Furlong et al., 2015; Montague \& Jitendra, 2012; Walcott \& Romain, 2019) mentally retarded children with dyscalculia are expected to have the ability to count (Pontius, 1983; Ramaa, 2014) so that they can navigate their daily lives more independently and do not depend on others (Purnami et al., 2020). For someone who has barriers to the function of intelligence, and barriers to social behavior, including barriers to learning functions such as dyscalculia to have good numeracy skills they must first be introduced to natural numbers. This means that the original number is the number that students learn at the earliest at the primary school (Kartini, 2018). If students with these obstacles are familiar with the natural numbers, learning number operations including other types of numbers will be relatively easy.

To help mentally retarded students with dyscalculia conditions, learning media is needed in learning mathematics, especially in number recognition material (Maroofi et al., 2018; Nuari et al., 2019; Nuari \& Prahmana, 2018; Pradani et al., 2015; Yunisa \& Fatmawati, 2018). The learning media used are intended so that the message conveyed by the teacher can be conveyed easily to them (Hakim et al., 2019; Saputro, 2016; Widodo et al., 2018; Trisniawati et al., 2019)). For the media to be effectively used by the teacher, the selection of media should be adjusted to the characteristics of students such as student conditions (Widodo, 2018), like the student characteristics referred to in this study which are students with mental retardation and discourse. Research conducted in Iran using the media using the Misha and Kusha educational software given to 100 students with mental disorders is proven to be effectively used to reduce learning disabilities (Maroofi et al., 2018). In Indonesia, ladder snake media is used to improve students' counting skills in dialysis students (Pradani et al., 2015), and there is the use of the 
number stick media to introduce numbers 1 to 10 to mentally retarded students (Yunisa \& Fatmawati, 2018).

In connection with these conditions, the purpose of this study was to determine the increase in the ability of mentally retarded students with dyscalculia to recognize natural numbers using learning media. The learning media used in the research is different from the media conducted by Maroofi et al (2018) using the educational software Misha and Kusha, Pradani et al (2015) with the media of snakes and ladders, and Yunisa \& Fatmawati (2018) with stick numbers. In this study, to improve the ability of mentally retarded students with dyscalculia media in the form of instructional videos were referred to. The video aims to convey a learning message to introduce natural numbers (numbers from 0 to 9) to students with intellectual and mental disability needs. The introduction of numbers is chosen because basic numbers must be known by anyone, hence if students already know these numbers, writing the next number will be easier (Gray, 1986; Weil, 2006). The learning video used is a combination of text, images, audio, and also animation so that it can attract students who watch it (Alksne, 2016; Saputri et al., 2018; Wang, 2014; Yeh, 2018). Based on this, the purpose of this study was to determine the increase in the ability of students with mental disabilities and in recognizing native numbers using video.

\section{Method}

\section{Model Research}

The research method used in this study is quantitative experiments with a single subject. Single Subject Research is a research with a single subject (Byiers et al., 2012; Freeman \& Eagle, 2011; Gast, 2009; Sunanto et al., 2005; Zhan \& Ottenbacher, 2001). Experimental research is a research method used to look for the effects of certain treatments that are controlled (Creswell, 2012). The Single Subject Research design used is the A-B design consisting of the baseline phase and the intervention phase as can be seen in Figure 1 (Byiers et al., 2012; Gast, 2009; Lovaas, 2003; Zhan \& Ottenbacher, 2001).

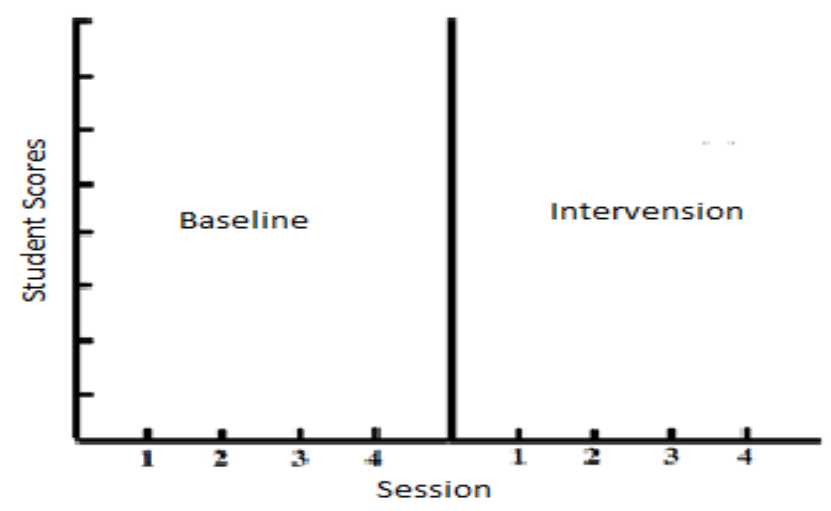

Figure 1. Research Design of Single Subject Research

The measurement of A-B design is done in a certain period for example weekly, per day, hourly, and the comparison is not done between individuals but to the same subject under different conditions (Freeman \& Eagle, 2011; Sunanto et al., 2005). In condition A is a baseline condition, meaning that the condition of the research subjects is not given a learning intervention using video. In other words, learning is carried out, as usual, namely learning that is carried out face-to-face with students without using any learning media. In this study, the 
baseline phase aims to determine the subject's ability to recognize natural numbers. If the subject is already emotionally close to the researcher, the research phase is continued at the next stage, which is the intervention phase. The intervention condition or condition B is the condition of the subject given the research intervention. Research subjects in the intervention phase were given learning treatment using video. This phase is different from the previous phase which did not use the intervention in the form of instructional videos. Often this intervention phase is called the experiment stage, although this experiment is given to one research subject as this type of research is a single subject.

\section{Participants}

The research subjects were selected using a purposive technique, meaning that the research subjects had to be adjusted to the characteristics of the study, the purpose of the study, and the subjectivity of the researchers to select subjects without leaving the researchers' code of ethics. The research subject used was a student with special needs, mental retardation, and dyscalculia. Furthermore, according to the research code of ethics, this subject is referred to as NB. He was a 13 year old fifth grade elementary school student with difficulty recognizing numbers. In addition, he is a mental retardation child with dyscalculia. This can be seen from the results of psychological examinations carried out by schools involving psychologists, showing that the subject is a mentally retarded child who has a level of intelligence that is classified as capable of educating with an IQ of 86. This is by the purpose of this study, which is to say to determine the increase in the ability of students with mental retardation and dyscalculia to recognize natural numbers, since this study requires subjects with mental retardation and dyscalculia.

\section{Data Collection}

In this study, for the learning process between researchers and NB to run well during the baseline and intervention phases, researchers needed a learning plan scenario in the form of a Hypothetical Learning Trajectory. Hypothetical Learning Trajectory (HLT) is a description of the learning process when students experience the learning process from the beginning until the learning objectives are achieved (Andrews-Larson et al., 2017; Simon \& Tzur, 2004). HLT refers to the teacher's plan based on the anticipation of student learning that might be achieved in the learning process based on the expected mathematics learning objectives of students, the knowledge and estimated level of understanding of students, and the choice of mathematical activities in sequence (Simon, 2017). The HLT is used as a guide in the research implementation process. The preparation of a hypothetical learning trajectory aims to anticipate the possibility of student learning and development to achieve learning objectives based on the knowledge already possessed by students and the estimated student understanding of the material. This is because the preparation of HLT is based on the analysis of learning barriers experienced by students.

Data collection techniques in this study were carried out using interviews, observations, and tests. Interviews were conducted to determine the characteristics and abilities of subjects according to parents. This is done so that researchers can prepare specific strategies to deal with research subjects who have mental retardation. This strategy is needed by researchers to build closeness between researchers and research subjects. The researcher chose the subject's parents as the source to know the habits because they are the people who are close to the research subject and know the habits of the research subject the most. Observations in this study were used to observe and record all the behavior of research subject both during the baseline phase and the intervention phase. Observations were made by describing the indicators the researcher 
wanted to achieve. The observation indicators were (1) the subject was enthusiastic during the lesson, (2) the subject understood the instructions and material presented by the researcher, and (3) the subject was able to work on the questions given. The observation sheet used is adjusted to the format shown in Figure 2.

\begin{tabular}{|l|l|l|l|}
\hline Research Phase & Date & \multicolumn{1}{|c|}{ Indicator } & \\
\hline \multirow{5}{*}{} & & $\begin{array}{l}\text { The subject was } \\
\text { enthusiastic during the } \\
\text { lesson }\end{array}$ & \\
\cline { 3 - 4 } & & $\begin{array}{l}\text { The subject } \\
\text { understood the } \\
\text { instructions and } \\
\text { material presented by } \\
\text { the researcher }\end{array}$ & \\
\hline & $\begin{array}{l}\text { The subject was able } \\
\text { to work on the } \\
\text { questions given }\end{array}$ & \\
\hline
\end{tabular}

Figure 2. Observation Sheet

The next data collection technique is a test used to measure the ability of research subjects to recognize numbers. This test is done verbally or in written format which is done in 2 ways. First, the subjects were given a prepared number card. After the subject is given a number card, the subject is asked to name the numeric name written on the card. For example, the researcher gives a card written with the number "6", the research subject is expected to say "six" to answer the question given by the researcher. Second, the research subjects were asked to write down and show the numbers mentioned by the researcher. For example, the researcher says the number "six", the research subject is expected to write the number " 6 " on existing paper or books or the subject points to the "6" card. In these two ways, there are 30 questions that are used to determine the ability of the research subject to recognize numbers, which make up 10 questions related to pointing numbers, 10 questions related to writing numbers, and 10 questions related to mentioning numbers.

\section{Data analysis}

After all the data needed for the research has been obtained by the researcher, the next step is to analyze the data. Researchers use Microsoft Excel to help calculate the data to be analyzed, while tables and figures are done manually. In this study, the data analysis used was a condition analysis and an analysis between conditions. Condition analysis is an analysis performed at baseline conditions or conditions of intervention (James, 2016; Sunanto et al., 2005). The components used to perform this condition analysis include (1) the duration of the condition; (2) trend direction; (3) the level of stability that can be determined by calculating the amount of data in the range of $50 \%$ above and below the average; (4) the rate of change, which can be calculated by finding the difference between the first data and the last data; (5) trace data, and (6) range, to put it in another way the distance between the first data and the last date, can be calculated by looking for the product with the highest score on the condition with stability criteria (0.15) (Freeman \& Eagle, 2011; Gast, 2009; Sunanto et al., 2005). Meanwhile, the analysis between conditions was carried out to see the difference between the baseline phase and the intervention phase (James, 2016; Sunanto et al., 2005). The components used to perform this condition analysis include (1) the changed variables; (2) changes in direction and effects, (3) changes in stability and effects, (4) changes in data levels, which can be seen by finding differences between the last data at baseline conditions and the first data on intervention conditions, and (5) overlapping data, which can be seen by determining the percentage between 
the same data in the two conditions with the same data on the conditions (Freeman \& Eagle, 2011; Gast, 2009; Sunanto et al., 2005).

\section{Result and discussion}

\section{Result}

The results of the measurement of the ability to recognize natural numbers on the subjects during the baseline phase until the intervention are presented as in table 1 . Table 1 is obtained from the results of the ability to recognize numbers consisting of the ability to name numbers, the ability to show numbers, and the ability to write numbers $0-9$. The baseline phase is the phase of learning the introduction of natural numbers without using learning videos to the subjects. The intervention phase is the introduction of natural numbers using video learning to subjects.

Table 1. Accumulated Score Ability to Recognize Numbers

\begin{tabular}{lll}
\hline \multirow{2}{*}{ Session } & \multicolumn{2}{l}{ Score } \\
\cline { 2 - 3 } & Baseline & Intervention \\
\hline 1 & 30 & - \\
2 & 30 & - \\
3 & 30 & - \\
4 & - & 53,33 \\
5 & - & 56,67 \\
6 & - & 60 \\
7 & - & 56,67 \\
8 & - & 60 \\
Average & 30 & 54 \\
\hline
\end{tabular}

From Table 1 it is found that the mean in the baseline phase, the phase in which NB subject with mental retardation and dyscalculia conditions before using the learning video reaches 30 . Because in the baseline phase for each session, NB was only able to answer the 9 questions given so the score obtained was $\frac{9}{30} x 100=30$. In the intervention phase, the NB subject in the $4^{\text {th }}$ session was able to answer the 16 questions given and the score obtained was $\frac{16}{30} \times 100=$ 53.33. NB in the $5^{\text {th }}$ and $7^{\text {th }}$ sessions were able to answer the 17 questions given therefore the score obtained was $\frac{17}{30} x 100=56.67$. In the $6^{\text {th }}$ and $8^{\text {th }}$ sessions, the NB subject was able to answer the 18 questions given hence the score obtained was $\frac{18}{30} x 100=60.00$. The average in the intervention phase, the phase where for NB subject with mental retardation and dyscalculia conditions video learning was used reaches 54 . The ability to recognize native numbers of NB subject experienced positive changes with a difference of 24 . Based on the data in table 1 , this can be presented in graphical form as shown in Figure 3. 


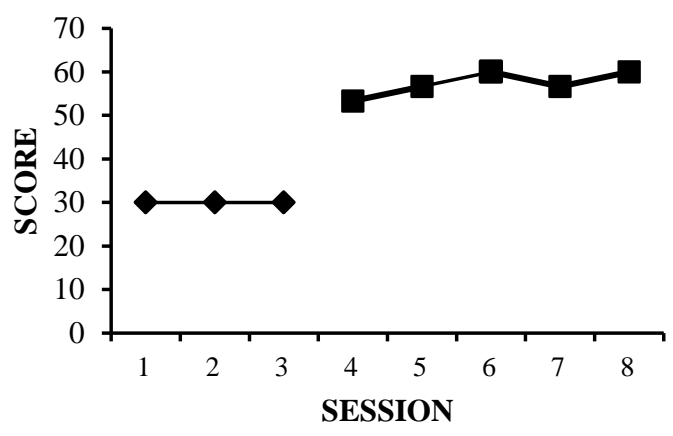

Figure 3. Visual Baseline Analysis and Interventions

Changes in the direction of the graph between the baseline conditions and the intervention show the meaning of the change in target behavior caused by the intervention. Based on Figure 1, the change in direction of the graph when the baseline conditions are straight up to trend compared to the intervention conditions. The change in the direction of the graph between the baseline conditions and the intervention shows that interactive media influences the ability to recognize numbers in mentally retarded children.

\section{Analysis under condition}

The condition length indicates the session for each condition. From table 1, it appears that the baseline A phase consisted of 3 sessions. The baseline phase generally aims to obtain an overview of research subjects related to the initial ability to recognize natural numbers. the intervention phase B consists of 5 sessions. This intervention phase aims to see the effect of the video used in mathematics learning on the introduction of natural numbers.

The estimation of direction trends is to see the development of behavior from session to session in each phase (Blankenship et al., 2016; Erlani et al., 2018; Setyawan, 2015). In this study, estimating the direction tendency was carried out by using the split-middle method. The results of the direction tendency estimation are shown in Figure 4.

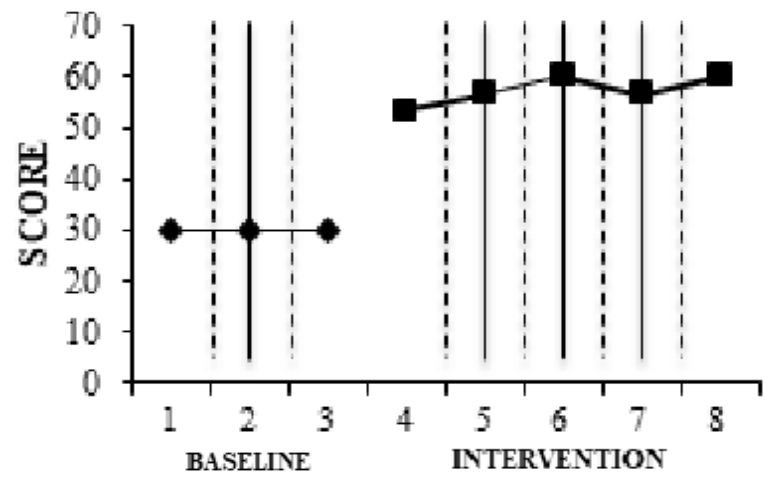

Figure 4. Estimation of Direction Trend

In the baseline phase $A$ to determine the stability trend with the $15 \%$ criterion, the calculation is

$\begin{array}{cccc}\text { Highest Score } & \times & \text { Stability criteria } & \text { Stability range } \\ 30 & \times & 0.15 & 4.5\end{array}$

Determine the mean level

Baseline data $\quad 30+30+30 \quad=90$ 
Mean level $90: 3$ $=30$

Determine the Upper Limit

Mean level $+\quad$ Half of the stability range

$\begin{array}{lll}30+ & 2.25 & =32.25\end{array}$

Determine the Lower Limit

Mean level - $\quad$ Half of the stability range
30
2.25
$=27.75$

Determine the percentage in the Stability Range

Many data points exist . The number of Percentage of stability in a range 3 - data points

: $3100 \%$

If the percentage of stability of $85 \%-90 \%$ is said to be stable (Sunanto et al., 2005), when it is below, it is said to be unstable (variable), because the calculation result for the baseline phase is $100 \%$, then a stable result is obtained.

In the intervention phase B to determine the tendency for stability with a $15 \%$ criterion, the calculation is

Highest Score 60 $\times \quad$ Stability criteria $\times \quad 0.15$ Stability range

Determine the mean level

Baseline data

Mean level

$$
53.33+56.67+60+56.67+60
$$
$286.67: 5$ 9

Determine the Upper Limit

Mean level + Half of the stability range

$\begin{array}{lll}57.33+4.5 & =61.83\end{array}$

Determine the Lower Limit

Mean level - $\quad$ Half of the stability range
57.33
4.5
$=52.83$

Determine the percentage in the Stability Range

$\begin{array}{llll}\text { Many data points exist } & \begin{array}{l}\text { The number of } \\ \text { data points }\end{array} & \text { Percentage of stability } \\ \text { in a range } & 5 & =100 \%\end{array}$

If the percentage of stability of $85 \%-90 \%$ is said to be stable, when below, it is unstable (variable), because the calculation result for the intervention phase is $100 \%$, then a stable result is obtained.

Table 2. Trends in trace data

\begin{tabular}{llll}
\hline Condition & A & & B \\
\hline Trends in Data Traces & $=$ & + \\
& & $=$ & + \\
\hline
\end{tabular}

To determine the data-trace in each phase is the same as determining the direction tendency. Table 2 is the trend of the data footprint in the baseline phase and the intervention phase. Baseline phase $\mathrm{A}$, the direction of the trend is written straight $(=)$ which means there is no decrease, and the intervention phase $\mathrm{B}$, the direction of the trend is written $(+)$, which means there is an increase. 
the level of change is determined by calculating the difference between the first and last data in each phase. Then, give a sign (+) if it improves, sign (-) if it gets worse, and (=) if there is no change. The level of change in conditions can be seen in table 3 .

Table 3. Level of Change

\begin{tabular}{lll}
\hline Condition & A & B \\
\hline Level of Change & $30-30=0 \quad(=)$ & $60-53,33=6,67 \quad(+)$ \\
\hline
\end{tabular}

\section{Inter Condition Analysis}

Variables that are changed from baseline conditions (A) to interventions (B) are the ability to recognize natural numbers. Changes in direction tendencies obtained from each phase on the ability of students to recognize natural numbers accordingly can be seen in table 4 .

Table 4. Change in Direction

\begin{tabular}{ll}
\hline Comparison of Conditions & B/A \\
\hline Change in direction &
\end{tabular}

Changes in data levels are obtained by determining the data points in the baseline conditions (A) in the last session (30) and the first session in the intervention conditions (B) namely (53.33), calculating the difference (30 - 53.33) then obtained ( 23.33$)$. Changes in levels from the baseline phase and the intervention phase can be seen in table 5 .

Table 5. Changes in Data Levels

\begin{tabular}{ll}
\hline Comparison of Conditions & B/A \\
\hline Level of change & $(30-53,33)=(-23,33)$ \\
\hline
\end{tabular}

To determine the percentage of overlap in the baseline conditions and interventions the following were performed: (1) reviewing the lower and upper boundaries of the baseline conditions, (2) calculating a lot of data points on the intervention conditions that are in the range of baseline conditions ie $0,(3)$ acquisition of numbers at step (2) divided by data points in the intervention condition then multiplied by $100 \%$, then $(0: 5) \times 100 \%=0 \%$. The smaller the overlap percentage, the better the effect of the intervention on the target behavior.

\section{Discussion}

Mathematics has an important role in life, in addition to functioning as a tool to solve problems, think logically, and rationally, and it also functions as a tool to facilitate relationships between individuals and as a tool for communication (National of Council Teacher of Mathematics, 2000b, 2000a; Stylianou et al., 2015; Widodo et al., 2019, 2020). However, learning mathematics becomes a difficult activity for mentally retarded children who experience dyscalculia. Developmental children have the characteristics of being slow in learning new things and have difficulty in focusing attention so they are less able when they have to learn like normal children. Besides that, dyscalculia is one form of learning disabilities in mentally retarded children. So students with mental retardation tend to have additional learning barriers such as dyscalculia. Therefore, interactive media are needed that can foster motivation and make it easier for mentally retarded children and intellectuals to deliver mathematics learning material. 
NB subject who is a child with mental retardation also had dyscalculia. Psychological examination results shows that NB is a mentally retarded child who has an intelligence level that is classified as being able to be educated with an IQ of 86 . NB is a fifth-grade elementary school student aged 13 years with difficulty in recognizing numbers. Thinking that knowing numbers is the initial stage of learning mathematics. It can be ascertained that NB has difficulty in learning mathematics.

In this study, the selection of numbers 0 - 9 are based on the Hindu-Arabic number system that is used today and is a number system used internationally. The process of recognizing numbers from 0 to 9 includes the introduction of numeric names, recognition of numeric forms, recognition of numeric names based on their shapes, and recognition of numeric forms based on their names. The results showed that the video was used by mentally retarded children with dyscalculia in activities to recognize numbers. This is supported by previous research which states that interactive learning media can be used to help students with special needs such as students with intellectual and mental disability. Although the results of previous studies show a positive effect in favor of using interactive media in learning, the learning media used in the present study are different. For instance, a research conducted by Marofi et al. (2018) in Iran using the Misha and Kusha educational software. Besides, there is research conducted by Pradani et al. (2015 using snakes and ladders, or research conducted by Yunisa \& Fatmawati (2018) with the number stick media to introduce numbers to students with special needs. This research uses interactive video media to introduce numbers to mentally retarded students with dyscalculia obstacles.

The test results in the baseline phase are used to determine the subject's initial ability to recognize numbers. On the ability test to mention the names of numbers, subjects can name 3 names of numbers, namely 1,2 , and 3 . On the ability tests to show numbers, subjects can show 3 numbers, namely 1,2 , and 3 whereas on the ability to write numbers tests, subjects can write 3 numbers, i.e. 1,2 , and 3 .

In the intervention phase, for each session the researchers introduced numbers using interactive media in the form of videos. Video as part of learning constitute a medium used to convey messages to students. This is in line with the opinion which states that learning media such as videos, comics, and power points are useful for conveying learning messages to students (Aryuntini et al., 2019; Fantin, 2011; Widodo et al., 2018). Through this video, subject were guided to remember names, numeric shapes, numeric names based on their shapes, and numeric shapes based on their names using video media. Besides, the researcher also invited the subject to play a number guessing game. Learning to guess numbers repeatedly will improve the ability to remember numbers.

The results of this study are parallel to the previous research which states that through guessing numbers using Android-based games can improve children's ability to recognize numbers 1-10 (Saputra et al., 2012). Besides, these results are also in line with the results of multimedia research used by teachers as alternative learning for children of preschool-age accommodating their needs (Fathimah \& Ishartiwi, 2018; Putri \& Suparno, 2020). The difference between this study and other research lies in the learning media used. By using instructional videos, mentally retarded students with dyscalculia can focus on the material provided by the researcher. As stated by Walcott \& Romain (2019) for mentally retarded students with dyscalculia, being able to focus during learning is essential. This is done so that his desire to learn is very strong. 


\section{Conclusion}

Based on the results of research and discussion, it can be concluded that interactive media influences the ability to recognize numbers in mentally retarded children who experience dyscalculia. The influence of interactive media can be seen by the change in data from the baseline phase to the intervention phase. In the ability test to recognize baseline phase numbers, subject was able to recognize 3 numbers, namely numbers 1, 2, and 3, and obtained scores with an average of 30 . While in the intervention phase, subject $w$ able to recognize 6 numbers namely $0,1,2,3,7$, and 8 ; and experienced a change in the average score to 54 . From these data, it can be seen that the ability to recognize the number experienced a change of 24 . From these data, it can be seen that there is a positive influence of interactive media on the ability to recognize numbers in mentally retarded children with dyscalculia.

\section{Recommendation}

In connection with the results of this study, it can be recommended that the use of interactive learning videos can be used as an alternative to learning media for mentally retarded students with dyscalculia. Besides, it is necessary to consider using similar media to improve the ability of mentally retarded students with dyscalculia in other numbers

\section{Reference}

Alksne, L. (2016). How to produce video lectures to engage students and deliver the maximum amount of information. Proceedings of the International Scientific Conference, 503(2), 503-516. https://doi.org/10.17770/sie2016vol2.1424

Andrews-Larson, C., Wawro, M., \& Zandieh, M. (2017). A hypothetical learning trajectory for conceptualizing matrices as linear transformations. International Journal of Mathematical Education in Science and Technology, 48(6), 809-829. https://doi.org/10.1080/0020739X.2016.1276225

Aryuntini, N., Astuti, I., \& Yuliana, Y. G. S. (2019). Development of learning media based on videoscribe to improve writing skill for descriptive text of english language study. JETL (Journal Of Education, Teaching and Learning), 3(2), 187.

Backenson, E. M., Holland, S. C., Kubas, H. A., Fitzer, K. R., Wilcox, G., Carmichael, J. A., Fraccaro, R. L., Smith, A. D., Macoun, S. J., Harrison, G. L., \& Hale, J. B. (2015). Psychosocial and adaptive deficits associated with learning disability subtypes. Journal of Learning Disabilities, 48(5), 511-522. https://doi.org/10.1177/0022219413511861

Bakare, M. O., Ubochi, V. N., Ebigbo, P. O., \& Orovwigho, A. O. (2010). Problem and prosocial behavior among nigerian children with intellectual disability: the implication for developing policy for school based mental health programs. Italian Journal of Pediatrics, 36(1). https://doi.org/10.1186/1824-7288-36-37

Baştürk, S. (2016). Secondary school mathematics student teachers' causal attribution for success and failure in mathematics. European Journal of Science And Mathematics Education, 4(3), 365-379.

Blankenship, P. A., Stuebing, S. L., Winter, S. S., Cheatwood, J. L., Benson, J. D., Whishaw, I. Q., \& Wallace, D. G. (2016). The medial frontal cortex contributes to but does not organize rat exploratory behavior. Neuroscience, 336, 1-11. https://doi.org/10.1016/j.neuroscience.2016.08.041

Bran, M., \& Bouleanu, E. L. (2017). Causal reasoning in mild mental disabled children. International Conference Knowledge-Based Organization, 23(2), 245-250. https://doi.org/10.1515/kbo-2017-0121

Bugden, S., \& Ansari, D. (2016). Probing the nature of deficits in the "approximate number 
system" in children with persistent developmental dyscalculia. Developmental Science, 19(5), 817-833. https://doi.org/10.1111/desc.12324

Byiers, B. J., Reichle, J., \& Symons, F. J. (2012). Single-subject experimental design for evidence-based practice. American Journal of Speech-Language Pathology, 21(4), 397414. https://doi.org/10.1044/1058-0360(2012/11-0036)

Chodura, S., Kuhn, J. T., \& Holling, H. (2015). Interventions for children with mathematical difficulties: a meta-analysis. Zeitschrift Fur Psychologie / Journal of Psychology, 223(2), 129-144. https://doi.org/10.1027/2151-2604/a000211

Creswell, J. W. (2012). Research Design Qualitative, Quantitative, and Mixed Second Edition. Sage Publication.

Dekker, M. C., Ziermans, T. B., \& Swaab, H. (2016). The impact of behavioural executive functioning and intelligence on math abilities in children with intellectual disabilities. Journal of Intellectual Disability Research, 60(1086-1096). https://doi.org/10.1111/jir.12276

Dowker, A., \& Sigley, G. (2010). Targeted interventions for children with arithmetical difficulties. British Journal of Educational Psychology, 60(11), 1086-1096. https://doi.org/10.1348/97818543370009x12583699332492

El-Keshky, M., \& Emam, M. (2015). Emotional and behavioural difficulties in children referred for learning disabilities from two Arab countries: a cross-cultural examination of the strengths and difficulties questionnaire. Research in Developmental Disabilities, 36, 459469. https://doi.org/10.1016/j.ridd.2014.10.039

Emam, M. M., \& Kazem, A. M. (2015). Teachers' perceptions of the concomitance of emotional behavioural difficulties and learning disabilities in children referred for learning disabilities in Oman. Emotional and Behavioural Difficulties, 36, 459-469. https://doi.org/10.1080/13632752.2014.964083

Erlani, L., Narawati, T., \& Alimin, Z. (2018). Using AAC media to improve dynamics ability in music learning for autistic children. International Journal of Pedagogy and Teacher Education, 2, 109-118. https://doi.org/10.20961/ijpte.v2i0.25140

Fantin, M. (2011). Perspectives on media literacy, digital literacy and information literacy. International Journal of Digital Literacy and Digital Competence, 1(4), 10-15. https://doi.org/10.4018/jdldc.2010100102

Fathimah, N. S., \& Ishartiwi, I. (2018). Pengembangan multimedia permainan interaktif pembelajaran berhitung bagi anak diskalkulia usia prasekolah. Jurnal Inovasi Teknologi Pendidikan, 5(2), 115-128. https://doi.org/10.21831/jitp.v5i2.15541

Freeman, K. A., \& Eagle, R. F. (2011). Single-subject research designs. In Understanding Research in Clinical and Counseling Psychology, Second Edition (pp. 124-154). https://doi.org/10.4324/9780203831700

Furlong, M., McLoughlin, F., McGilloway, S., \& Butterworth, B. (2015). Interventions to improve mathematical outcomes for children with dyscalculia. In Cochrane Database of Systematic Reviews.

Gast, D. L. (2009). Single subject research methodology in behavioral sciences. In special education and behavioral sciences. Routledge. https://doi.org/10.4324/9780203877937

Gray, J. (1986). Number theory: An approach through history from Hammurapi to Legendre. In Historia Mathematica. https://doi.org/10.1016/0315-0860(86)90242-9

Hakim, L. L., Alghadari, F., \& Widodo, S. A. (2019). Virtual manipulatives media in mathematical abstraction. Journal of Physics: Conference Series. https://doi.org/10.1088/1742-6596/1315/1/012017

Harvey, H. A., \& Miller, G. E. (2017). Executive function skills, early mathematics, and vocabulary in head start preschool children. Early Education and Development, 28(3), 290-307. https://doi.org/10.1080/10409289.2016.1218728 
Hegde, S., \& Bhaskar, S. A. (2015). Oral myiasis: a concealed threat to disabled children of developing countries. Journal of Dentistry for Children, 82(2), 112-115.

James, K. P. (2016). Single-subject research method: the needed simplification. British Journal of Education, 4(6), 68-95. www.eajournals.org

Kartini, R. (2018). Improving Learning outcomes of mathematics lesson through roman numeral puzzle at fourth grade elementary school students in Malang. Advances in Social Science, Education and Humanities Research (ASSEHR), 147(ICSSE 2017), 245-246. https://doi.org/10.2991/icsse-17.2018.57

Kucian, K., \& von Aster, M. (2015). Developmental dyscalculia. European Journal of Pediatrics, 174(1), 1-13. https://doi.org/10.1007/s00431-014-2455-7

Kumar, S., Sharma, J., Duraiswamy, P., \& Kulkarni, S. (2009). Determinants for oral hygiene and periodontal status among mentally disabled children and adolescents. Journal of Indian Society of Pedodontics and Preventive Dentistry, 27(3). https://doi.org/10.4103/0970-4388.57095

Lovaas, O. I. (2003). Teaching Individuals With Developmental Delays: Basic Intervention Techniques. Pro-ed.

Maroofi, Y., Rad, A. M., \& Ehteshami, M. Z. (2018). Effectiveness of educational multimedia method on reducing mental- disorders in third-elementary students. Middle Eastern Journal of Disability Studies, 8(75), 1-7.

Martin, A. J., Cumming, T. M., O’Neill, S. C., \& Strnadová, I. (2017). Social and emotional competence and at-risk children's well-being: The roles of personal and interpersonal agency for children with ADHD, emotional and behavioral disorder, learning disability, and developmental disability. In Social and Emotional Learning in Australia and the AsiaPacific: Perspectives, Programs and Approaches. https://doi.org/10.1007/978-981-103394-0_7

Montague, M., \& Jitendra, A. K. (2012). Research-based mathematics instruction for students with learning disabilities. In Forgasz H \& Rivera F (Eds.), Towards Equity in Mathematics Education. Springer Berlin Heidelberg. https://doi.org/10.1007/978-3-642-27702-3_44

National of Council Teacher of Mathematics. (2000a). Curricullum and Evaluation Standards for School Mathematics (VA (ed.)). NCTM.

National of Council Teacher of Mathematics. (2000b). Principles and Standards For School Mathematics. NCTM.

Nuari, L. F., \& Prahmana, R. C. I. (2018). Kemampuan operasi hitung perkalian dan pembagian siswa tunagrahita kelas X SMA. Joornal of Songke Math, 1(1), 12-25.

Nuari, L. F., Prahmana, R. C. I., \& Fatmawati, I. (2019). Learning of division operation for mental retardations' student through math gasing. Journal on Mathematics Education, 10(1), 127-142. https://doi.org/10.22342/jme.10.1.6913.127-142

Pontius, A. A. (1983). Finger misrepresentation and dyscalculia in an ecological context: toward an ecological (cultural) evolutionary iwuro-psychiatry. Perceptual and Motor Skills, 57, 1191-1208.

Pradani, L., Lestari, S., \& Wibowo, W. A. (2015). Metode permainan ular tangga untuk meningkatkan keterampilan berhitung pada anak diskalkulia. Proseding Seminar Nasional PGSD UPY, 163. http://repository.upy.ac.id/408/1/artikel linggar.pdf

Price, G. R., \& Ansari, D. (2013). Developmental dyscalculia. In Handbook of Clinical Neurology. https://doi.org/10.1016/B978-0-444-52891-9.00025-7

Purnami, A. S., Mulyoto, M., \& Winoto, B. (2020). Android-based shopping skill for mentallydisable student. Journal of Education and Learning (EduLearn), 14(3), 411-415. https://doi.org/10.11591/edulearn.v14i3.16110

Putri, A. A., \& Suparno. (2020). Recognize geometry shapes through computer learning in early math skills. Jurnal Pendidikan Usia Dini, 14(1), 43-57. 
https://doi.org/10.21009/jpud.141.04

Ramaa, S. (2014). Arithmetic difficulties among socially disadvantaged children and children with dyscalculia. In S. Chinn (Ed.), The Routledge International Handbook of Dyscalculia and Mathematical Learning Difficulties (pp. 146-166). Routledge.

Saputra, V. H., Darwis, D., \& Febrianto, E. (2012). Rancang bangun aplikasi game matematika untuk penyandang tunagrahita berbasis mobile. Jurnal Komputer Dan Informatika, 15(1), 171-181.

Saputri, D. Y., Rukayah, R., \& Indriayu, M. (2018). Need assessment of interactive multimedia based on game in elementary school: a challenge into learning in $21^{\text {st }}$ century. International Journal of Educational Research Review, 3(3), 1-8. https://doi.org/10.24331/ijere.411329

Saputro, B. A. (2016). Learning media development approach with a rectangle problem posing based geogebra. Infinity: Journal of Mathematics Education, 6(2), 121-130.

Scherer, P., Beswick, K., DeBlois, L., Healy, L., \& Opitz, E. M. (2017). Assistance of students with mathematical learning difficulties: how can research support practice? Proceedings of the 13th International Congress on Mathematical Education, 249-259. https://doi.org/10.1007/s11858-016-0800-1

Setyawan, O. G. (2015). Pengaruh penggunaan media teka-teki silang bergambar terhadap penguasaan kosakata peserta. Jurnal Ortopedagogia, 1(4), 289-295.

Shalev, R. S., \& Gross-Tsur, V. (2001). Developmental dyscalculia. Pediatric Neurology, 24(5), 337-342. https://doi.org/10.1016/S0887-8994(00)00258-7

Simon, M. A. (2017). Explicating mathematical concept and mathematicalconception as theoretical constructs for mathematics education research. Educational Studies in Mathematics, 94(2), 117-137. https://doi.org/10.1007/s10649-016-9728-1

Simon, M. A., \& Tzur, R. (2004). Explicating the role of mathematical tasks in conceptual learning: an elaboration of the hypothetical learning trajectory. Mathematical Thinking and Learning, 6(2), 91-104. https://doi.org/10.1207/s15327833mt10602_2

Skagerlund, K., \& Träff, U. (2016). Number processing and heterogeneity of developmental dyscalculia: subtypes with different cognitive profiles and deficits. Journal of Learning Disabilities, 49(1), 36-50. https://doi.org/10.1177/0022219414522707

Sridevi, G., George, A. ., Sriveni, D., \& Rangaswami, K. (2015). Learning disability and behavior problems among school going children. Journal of Disability Studies, 1(1), 4-9.

Stylianou, D. A., Blanton, M. L., \& Rotou, O. (2015). Undergraduate students' understanding of proof: relationships between proof conceptions, beliefs, and classroom experiences with learning proof. International Journal of Research in Undergraduate Mathematics Education, 1(1), 91-134. https://doi.org/10.1007/s40753-015-0003-0

Suchyadi, Y., Ambarsari, Y., \& Sukmanasa, E. (2018). Analysis of social interaction of mentally retarded children. JHSS (Journal Of Humanities And Social Studies), 2(2), 1721. https://doi.org/10.33751/jhss.v2i2.903

Sunanto, J., Takeuchi, K., \& Nakata, H. (2005). Pengantar penelitian dengan subyek tunggal. In CRICED University of Tsukuba. https://doi.org/10.5607/en.2016.25.1.33

Teixeira, S. A., Santos, P. C. M., Batista, A. R., Albuquerque, B. N., Vasconcelos, M., \& Borges-Oliveira, A. C. (2015). Assessment of oral hygiene in mentally disabled children. Revista Odonto Ciencia, 30(3). https://doi.org/10.15448/1980-6523.2015.3.12849

Torres-Carrión, P., Sarmiento-Guerrero, C., Torres-Diaz, J. C., \& Barba-Guamán, L. (2018). Educational math game for stimulation of children with dyscalculia. International Conference on Information Theoretic Security, 614-623. https://doi.org/10.1007/978-3319-73450-7_58

Trisniawati, Muanifah, M. T., Widodo, S. A., Ardiyaningrum, M. (2019). Effect of Edmodo towards interests in mathematics learning. Journal of Physics: Conference Series, 1188(1). 
https://doi.org/10.1088/1742-6596/1188/1/012103

Van Schooneveld, M. M. J., Braun, K. P. J., Van Rijen, P. C., Van Nieuwenhuizen, O., \& Jennekens-Schinkel, A. (2016). The spectrum of long-term cognitive and functional outcome after hemispherectomy in childhood. European Journal of Paediatric Neurology, 20(3), 376-384. https://doi.org/10.1016/j.ejpn.2016.01.004

Walcott, P., \& Romain, N. (2019). Using digital games to enhance the mathematical skills of children with dyscalculia. Journal of Education and Development in the Caribbean, 18(2), 88-110. https://doi.org/10.46425/j418025822

Wang, Z. (2014). An analysis on the use of video materials in college english teaching in china. International Journal of English Language Teaching, 2(1), 23-28. https://doi.org/10.5430/ijelt.v2n1p23

Weil, A. (2006). Number Theory: An Approach through History, from Hammurapi to Legendre. Springer Science \& Business Media.

Widodo, S. A. (2018). Selection of learning media mathematics for junior school students. Turkish Online Journal of Educational Technology - TOJET, 17(1), 154-160.

Widodo, S. A., Dahlan, J. A., Harini, E., \& Sulistyowati, F. (2020). Confirmatory factor analysis sosiomathematics norm among junior high school student. International Journal of Evaluation and Research in Education (IJERE), 9(2), 448-455. https://doi.org/10.11591/ijere.v9i2.20445

Widodo, S. A., Dahlan, J. A., \& Turmudi. (2019). Can sociomathematical norms be developed with learning media? Journal of Physics: Conference Series, 1315(1). https://doi.org/10.1088/1742-6596/1315/1/012005

Widodo, S. A., Darhim, \& Ikhwanudin, T. (2018). Improving mathematical problem solving skills through visual media Improving mathematical problem solving skills through visual media. Journal of Physics: Conf. Series, 948(1), 1-6. https://doi.org/10.1088/17426596/948/1/012004

Yeh, H. C. (2018). Exploring the perceived benefits of the process of multimodal video making in developing multiliteracies. Language Learning and Technology, 22(2), 28-37. https://doi.org/10.125/44642

Yunisa, R., \& Fatmawati, F. (2018). Media stick angka untuk meningkatkan pemahaman konsep bilangan 1 sampai 5 bagi anak tunagrahita ringan. Jurnal Penelitian Pendidikan Khusus, 6(2), 289-296.

Zhan, S., \& Ottenbacher, K. J. (2001). Single subject research designs for disability research. Disability and Rehabilitation, 23(1), 1-8. https://doi.org/10.1080/09638280150211202 